\title{
A gyógyszer által indukált állcsontnecrosis-kockázat mértékének meghatározása az általános fogorvosi gyakorlatban
}

\author{
Zurányi Anna dr. - Vasziné Szabó Enikő dr. - Tóth Zsuzsanna dr. \\ Semmelweis Egyetem, Fogorvostudományi Kar, Konzerváló Fogászati Klinika, Budapest
}

\begin{abstract}
A gyógyszer indukálta osteonecrosis antireszorptív terápia szövődményeként léphet fel, kezelése komoly kihívást jelent. A betegség 2003. évi leírását követően a gyógyszer indukálta osteonecrosis kialakulásában szerepet játszó szisztémás és lokális rizikófaktorokat gyüjtöttük össze. A rizikófaktorokat a PubMed-adatbázisban az 1998 és 2018 közötti időszakban megjelent irodalmi kutatások alapján rendszereztük. A kockázattal élő pácienseink három csoportja: antireszorptív terápiát még nem megkezdettek, már antireszorptív terápiában részesülők, manifeszt osteonecrosisban szenvedők. A fogorvos feladata a rizikófaktorok felmérése, ennek megfelelő kezelési terv felállítása, a kontrollvizsgálatok gyakoriságának megszabása. Az antireszorptív terápiák közül az onkológiai indikációval kapott intravénás kezelés jelenti a legnagyobb kockázatot. További szisztémás rizikófaktorok: járulékos terápia, kísérő betegség, életmód, személyi tényezők. A lokális rizikófaktorok a következők: dentoalveolaris sebészi beavatkozás, periapicalis és parodontalis gyulladások, rosszul illeszkedő kivehető fogpótlások, anatómiai eltérések. A rizikófaktorok halmozódása határozza meg a necrosis kialakulásának valószínúségét. Az osteonecrosis kialakulásának akkor a legkisebb a valószínûsége, ha a beteg a biszfoszfonátterápiát szanált fogazati statusszal kezdi meg.
\end{abstract}

Orv Hetil. 2019; 160(7): 243-251.

Kulcsszavak: MRONJ-rizikófaktor, antireszorptív terápia, fogászati prevenció

\section{Risk assessment of medication-related osteonecrosis of the jaw in general dental practice}

Medication-related osteonecrosis of the jaw may appear as adverse effect in antiresorptive therapy. Its successful treatment is challenging. We aimed to gather the systemic and local factors playing a role in etiology, published after its recognition. Risk factors were collected from the PubMed database 1998-2018. The three main groups of risk patients are: patients starting, patients having antiresorptive therapy, osteonecrosis diagnosed patients. The dentist must recognize risk factors, determine appropriate treatment plan and frequency of check-ups. Oncological disease treated intravenously means the greatest risk. Further systemic risk factors are: supportive therapies, concomitant disease, way of life, individual factors. Local risk factors may be: dentoalveolar surgery, periapical and periodontal inflammation, ill-fitting denture, presence of some anatomical structures. The accumulation of risk factors determines the probability of the manifestation of osteonecrosis. The most favorable case is patient starting antiresorptive therapy with a dental status needing no treatment.

Keywords: MRONJ risk factors, antiresorptive therapy, dental prevention

Zurányi A, Vasziné Szabó E, Tóth Zs. [Risk assessment of medication-related osteonecrosis of the jaw in general dental practice]. Orv hetil. 2019; 160(7): 243-251.

(Beérkezett: 2018. május 30.; elfogadva: 2018. szeptember 28.) 


\section{Rövidítések}

AAOMS $=$ (American Association of Oral and Maxillofacial Surgeons) Amerikai Arc-, Állcsont- és Szájsebészeti Társaság; $\mathrm{AB}=$ antibiotikum; ATP = adenozin-trifoszfát; $\mathrm{CHX}=$ klórhexidin; $\mathrm{GnRH}=$ (gonadotropin-releasing hormone) gonadotropinfelszabadító hormon; iv. = intravénás; MOTESZ = Magyar Orvostársaságok és Egyesületek Szövetsége; MRONJ $=($ medication-related osteonecrosis of the jaw $)$ gyógyszer által indukált állcsontnecrosis; NBP = aminobiszfoszfonát; RANK$\mathrm{L}=$ (receptor activator of nuclear factor kappa-B ligand) a kappa-B nukleáris faktor receptor aktivátorának ligandja; VEGF = (vascular endothelial growth factor) vascularis endothelialis növekedési faktor

A gyógyszer által indukált állcsontnecrosis (MRONJ-) rizikópáciensek felismerése igen alapos anamnézisfelvételt követel meg. Ismernünk kell azokat a gyógyszerkészítményeket, amelyek antireszorptív, illetve antiangiogenikus hatásúak, és azokat a betegségeket, amelyek ilyen terápiát igényelnek. Az antireszorptív hatású készítményeknek három nagy csoportját különböztetjük meg: az aminobiszfoszfonátokat (NBP), a nem aminobiszfoszfonátokat és a RANK-L-inhibitorokat. A biszfoszfonátok elsősorban azokba a csontokba épülnek be, amelyekben intenzív a csontátépülés [1], mint például a hosszú csöves csontok, illetve az állkapocs. Az aminobiszfoszfonátok specifikusan az osteoclastokon fejtik ki hatásukat, a farnezil-pirofoszfát-szintáz enzimet gátolva, mely az osteoclastok számára létfontosságú fehérjéket gátol [2], ezzel előidézve a sejtek apoptózisát [3]. A nem aminobiszfoszfonátok az adenozin-trifoszfátokba (ATP) beépülve bekerülnek az osteoclastok belsejébe, és itt fejtik ki citotoxikus hatásukat az intracelluláris folyamatok [4] gátlása révén. RANK-L-inhibitor a denoszumab, egy monoklonális humán antitest, amely a RANK-ligandhoz kötődve gátolja az osteoclastok érését és múködését. Ezzel csökken a csontreszorpció [5]. Nem biszfoszfonát típusú, de mellékhatásként állcsont-osteonecrosist okozhatnak a következő gyógyszerek is: vascularis endothelialis növekedési faktor (vascular endothelial growth factor - VEGF) inhibitor, bevacizumab és a tirozin-kináz-inhibitor szunitinib [6].

A MRONJ-rizikópáciensek köre igen széles. Antireszorptív terápiában részesülhetnek a csontmetasztázist adó, illetve hypercalcaemiával járó szolid tumoros betegek és a myeloma multiplexben szenvedő páciensek. A csontáttétet adó szolid tumorok: az emlórák, a prosztatarák, a tüdőrák és a vesesejtes carcinoma. A metasztázis megelőzésében nemcsak a csontremodelling gátlása (antireszorptív hatás), hanem az érképződés gátlása (antiangiogenikus hatás) is fontos. $\mathrm{Az}$ osteometabolicus zavarral rendelkező betegek egy része Paget-kórban szenved, de nagy részük osteoporosisos páciens. A csontritkulásnak számos oka lehet, kialakulhat a kor előrehaladtával, rheumatoid arthritis esetén, hyperparathyreosisban, hormonpótló terápiában nem részesülő posztmenopauzális nőknél és olyan onkológiai betegek- nél, akik hormonellenes terápiában [antiösztrogén, antiandrogén, aromatázenzim-inhibitor, gonadotropinfelszabadítóhormon (GnRH)-antagonista] részesülnek. Tirozin-kináz-inhibitor-kezelésben részesülnek a gastrointestinalis stromalis tumorban, kissejtes tüdőrákban, pajzsmirigy-carcinomában és malignus hematológiai kórképekben szenvedők [6].

A mindennapi fogorvosi gyakorlatban gyakran találkozunk érintett betegekkel.

\section{Célkitüzés}

Cél a MRONJ prevenciója a mindennapi fogorvosi gyakorlatban. Irodalmi adatok segítségével célunk volt öszszegyújteni azokat a szisztémás és lokális rizikófaktorokat, amelyek hozzájárulhatnak a MRONJ kialakulásához. A szisztémás faktorok adottak, hiszen ezek az általános anamnézisben szerepelnek. A lokális faktorok azok, amelyeket a fogorvos befolyásolni tud. Ezen faktorok közül a gyulladásos elváltozásokat gyógyítani, a mechanikus okokat kiiktatni kell.

\section{Módszer}

A MRONJ kialakulásában szerepet játszó rizikófaktorok összességét a PubMed-adatbázisban az 1998 és 2018 közötti idôszakban megjelent irodalmi kutatások alapján gyúijtöttük össze, „MRONJ-rizikófaktorok” kulcsszóval. Felhasználtuk a letölthető publikációk irodalmi forrásait is. Csak azokat a publikációkat használtuk, amelyek teljes szövege elérhető volt számunkra.

\section{Megbeszélés}

A MRONJ multifaktoriális betegség. Patomechanizmusa még nem ismert, de kialakulásához a következő etiológiai faktorok járulhatnak hozzá: gyulladás, fertőzés, lokális toxicitás és bizonyos készítmények antiangiogenikus hatása [7]. A nemzetközi publikációk alapján a MRONJ kialakulásának valószínúsége $0,1 \%$-ra tehető [8]. Kezelésének megkezdése előtt fontos a mindenre kiterjedő anamnézis felvétele, a klinikai és radiológiai vizsgálat, amelyek alapján a betegség kialakulásában szerepet játszó rizikófaktorok felderíthetők. A rizikótényezőket szisztémás és lokális faktorok szerint csoportosíthatjuk.

\section{Szisztémás rizikótényezők}

Szisztémás rizikótényezők fontossági sorrendben: az alkalmazott antireszorptív készítmény típusa, az alkalmazás módja, a terápia időtartama, a kezelt betegség típusa, járulékos terápia, társbetegségek és az életmóddal kapcsolatos, illetve személyi tényezók. A következókben ezek a rizikótényezők kerülnek kifejtésre [9]. 
Az antireszorptív készítmények típusa szerint megkülönböztetünk NBP-okat, nem aminobiszfoszfonátokat és RANK-L-inhibitorokat. Az NBP, mint például a zoledronsav, magas rizikót jelent a MRONJ kialakulása szempontjából, mert antireszorptív hatása mellett antiangiogenikus, érképződést gátló hatással is bír $[10,11]$. Vescovi klinikai vizsgálatában 205, MRONJ-jal diagnosztizált beteg $54,6 \%$-a zoledronsav-kezelésben részesült, fogászati anamnézisükben dentoalveolaris sebészi beavatkozás nem szerepelt. A sebészi beavatkozással összefüggésbe hozható 362, MRONJ-jal diagnosztizált esetben a betegek 69\%-a kapott zoledronsavat [9]. A MRONJ incidenciája a zoledronsav, illetve egyéb intravénás biszfoszfonátkészítmények esetében a kezelés időtartamával nő [10].

Qi és mtsai 8963 páciensen végzett metanalízise alapján az állcsont-osteonecrosis incidenciája a denoszumabkezelésben részesülőknél 1,7\% volt [12]. Vizsgálatuk azt az eredményt adta, hogy a denoszumabkezelésben részesülő pácienseknél nagyobb valószínúséggel alakulhat ki állcsont-osteonecrosis, mint a biszfoszfonáttal kezelteknél $[12,13]$.

Nem közömbös, hogy a páciens milyen formában kapja a gyógyszert. Intravénás adagolás esetén nagyobb valószínűséggel alakulhat ki MRONJ, mint orális adagolás mellett. A MRONJ incidenciája tumoros betegeknél, akik intravénás kezelésben részesülnek, 3,2\%, míg osteoporosis ellen kapott per os biszfoszfonátadagolás mellett $0,15 \%$ [14]. Az aminobiszfoszfonátok közül a zoledronsav jelenti a legnagyobb kockázatot, ennél kisebb rizikót jelentenek a következő intravénásan adható készítmények: ibandronsav, pamidronsav, etidronsav [10].

Lényeges tényező a szedett gyógyszer kumulatív dózisa és a kezelés időtartama $[10,11,15]$. Palaska és mtsai szerint a szájon át adagolt aminobiszfoszfonátterápia kezdete után átlagosan 4,5 évvel később jelent meg a MRONJ. Intravénás aminobiszfoszfonátkezelésnél, például zoledronsav esetében, átlagosan 2,5 év kell a kialakuláshoz [16].

A kezelő fogorvos feladata, hogy kiderítse az antireszorptív kezelés háttérbetegségét. A kezelés indikációja lehet osteometabolicus és onkológiai betegség is [11] (1. táblázat).

Az onkológiai indikációval kezelt pácienseknél nagyobb a MRONJ kialakulásának veszélye, különösen a myeloma multiplexben szenvedőknél. Egyes tanulmányok szerint a daganatos betegek esetén ez a vesély 3-18\% közé tehető, míg osteometabolicus kórelőzménynyel $0,02-11 \%$ [17]. Az orális antireszorptív kezelésben részesülő osteoporosisos pácienseknél 100-szor kisebb a MRONJ kialakulásának valószínüsége, mint az intravénás antireszorptív kezelésben részesülő daganatos betegeknél [11].

Szupportív kezelések is növelhetik a MRONJ kialakulásának veszélyét. Tumorkezelésnél a kapott kemoterápia is rizikófaktornak minősül, az immunszuppresszív tulajdonsága miatt [18]. Biszfoszfonát mellett kapott sztero-
1. táblázat $\mid A z$ antireszorptív terápia indikációi

\begin{tabular}{ll}
\hline Osteometabolicus betegség & $\begin{array}{l}\text { Onkológiai betegség } \\
\text { Kyeloma multiplex }\end{array}$ \\
$\begin{array}{l}\text { Porral járó osteoporosis } \\
\text { Rheumatoid arthritishez társuló } \\
\text { osteoporosis }\end{array}$ & $\begin{array}{l}\text { Szolid tumor csontáttétének } \\
\text { prevenciója }\end{array}$ \\
$\begin{array}{l}\text { Hyperparathyreosis } \\
\text { Antiösztrogén/antiandrogén } \\
\text { terápiához társuló osteoporosis }\end{array}$ & \\
Paget-kór
\end{tabular}

2. táblázat | Szisztémás rizikótényezők

\begin{tabular}{|c|c|}
\hline \multicolumn{2}{|l|}{ Szisztémás rizikótényezők } \\
\hline Antireszorptív gyógyszer & $\begin{array}{l}\text { A molekula típusa: } \\
\text { - aminobiszfoszfonát } \\
\text { - nem aminobiszfoszfonát } \\
\text { - RANK-L-inhibitor } \\
\text { A gyógyszeradagolás módja: } \\
\text { - tabletta } \\
\text { - intravénás } \\
\text { A kezelés időtartama }\end{array}$ \\
\hline Kezelt betegség & $\begin{array}{l}\text { - Myeloma multiplex } \\
\text { - Szolid tumor } \\
\text { - Csontmetabolicus betegség }\end{array}$ \\
\hline Járulékos terápia & $\begin{array}{l}\text { - Kemoterápia } \\
\text { - Szteroidkezelés } \\
\text { - Antiangiogenikus terápia: VEGF- } \\
\text { inhibitor, tirozin-kináz-inhibitor } \\
\text { - Erythropoeticus stimulálófaktorok }\end{array}$ \\
\hline Kísérő betegségek & $\begin{array}{l}\text { - Diabetes } \\
\text { - Rheumatoid arthritis } \\
\text { - Hypocalcaemia } \\
\text { - Dialízis } \\
\text { - Anaemia }\end{array}$ \\
\hline Életmód & $\begin{array}{l}\text { - Elhízás } \\
\text { - Alkoholfogyasztás } \\
\text { - Dohányzás }\end{array}$ \\
\hline Személyi tényezők & $\begin{array}{l}\text { - Nem } \\
\text { - Genetikai faktorok } \\
\text { - Életkor }\end{array}$ \\
\hline
\end{tabular}

RANK-L = a kappa-B nukleáris faktor receptor aktivátorának ligandja; VEGF $=$ vascularis endothelialis növekedési faktor

idkezelés esetén megfigyelték, hogy a MRONJ gyorsabban és súlyosabb formában manifesztálódik, és a kezelésre is nehezebben reagál [19]. Az antiangiogenikus kezelés az NBP-terápia mellett szintén a MRONJ kofaktora lehet [20].

Az idősebb korosztálynál gyakoriak az anamnézisben az egyéb kísérő betegségek. Ezeket sem lehet figyelmen kívül hagyni. A diabetes renyhébb mikrocirkulációt okoz, lassítja a sebek gyógyulását. A rheumatoid arthritis gyakran társul osteoporosissal. A hypocalcaemia és a hyperparathyreoidismus a csontmetabolizmus zavarával jár, szekunder osteoporosist okozva. A vesedialízis felbo- 
ríthatja az ionháztartást. Az ösztrogénhiányos állapotban kapott antiösztrogénterépia is rizikófaktorként szerepelhet [21]. Az anaemiás állapotok tovább rontják a mikrocirkulációt, ezzel hozzájárulva az avascularis MRONJ megjelenéséhez. A coagulopathiák önmagukban is okozhatnak osteonecrosist [22].

Az antireszorptív készítménnyel kezelt betegség és a járulékos terápiák mellett befolyásoló tényező az életmód, az elhízás, valamint a káros szenvedélyek, mint például a dohányzás és az alkoholfogyasztás [23]. Lényeges az életkor is, mert a korral párhuzamosan minden évtizeddel 9\%-kal nő a MRONJ incidenciája [15]. Bizonyos genetikai faktorok is hajlamosító tényezőként szerepelhetnek [18, 24]. Yang és mtsai génszekvenálási vizsgálatukban felderítették az állcsont-osteonecrosissal kapcsolatos génváltozatokat a biszfoszfonáttal kezelt európai populációban, mely a következő: a SIRTl/HERC4 locus a 10-es kromoszómán [24]. Az említett szisztémás rizikófaktorokat a 2. táblázatban gyújtöttük össze.

\section{Lokális rizikótényezốk}

A szisztémás tényezők felderítése után következik a lokális rizikótényezôk meghatározása: invazív dentoalveolaris sebészi beavatkozás és implantáció, patológiás folya- matok, mint a periapicalis és parodontalis gyulladások, periimplantitis, anatómiai adottságok és ennek kapcsán a rosszul illeszkedő kivehető fogpótlások.

A legtöbb manifeszt MRONJ-páciens korábban dentoalveolaris sebészi beavatkozáson esett át [11, 25]. A beavatkozások között a fogeltávolítás a leggyakoribb oki tényező $[11,26,27]$. Vescovi retrospektív vizsgálata alapján ez az esetek 99,7\%-ára igaz [9] (1.ábra).

Fogászati implantátum beültetésének szövődményeként is felléphet a gyógyszer indukálta osteonecrosis, ennek valószínüsége $0,3 \%$ [9]. A betegség kialakulását nagyban elősegíti, ha a páciens intravénás formában onkológiai indikációval kap hosszan tartó biszfoszfonátkezelést. Osteoporosisos betegek esetében a szövődmény kisebb gyakorisággal lép fel. A 2014. évi MOTESZ-állásfoglalás szerint Magyarországon a biszfoszfonátkezelés kontraindikálja az implantációt [28]. A csont védekezőképessége ugyanis csökken a hosszan tartó biszfoszfonátkezelés miatt. A csont-implantátum között nincs védekezési vonal, így az implantátum mellett nő a periimplantitis veszélye is [22].

A rossz szájhigiéné, illetve a szájüregben jelen lévő gyulladások a MRONJ-páciensek nagy részénél tapasztalható (2. ábra). A betegek 84\%-nál tapasztalható parodontalis gyulladás jelenléte [29]. Az invazív beavatkozás-

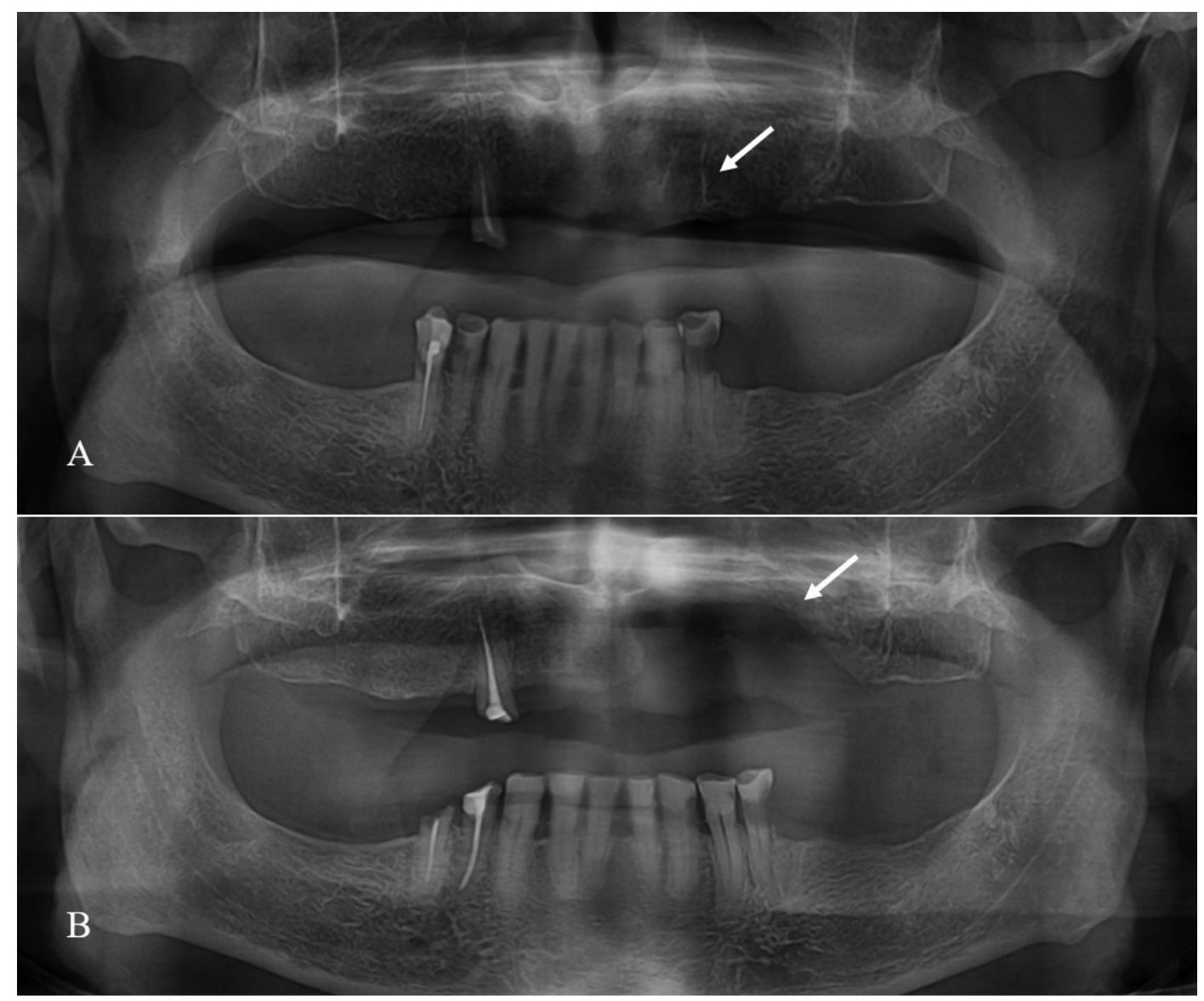

1. ábra Áttétes prosztatadaganatos páciens denoszumabkezelésben részesül. A beteg 23-as fogát eltávolították (A). Az extrakciót követően MRONJ alakult ki (B) MRONJ = gyógyszer által indukált állcsontnecrosis 


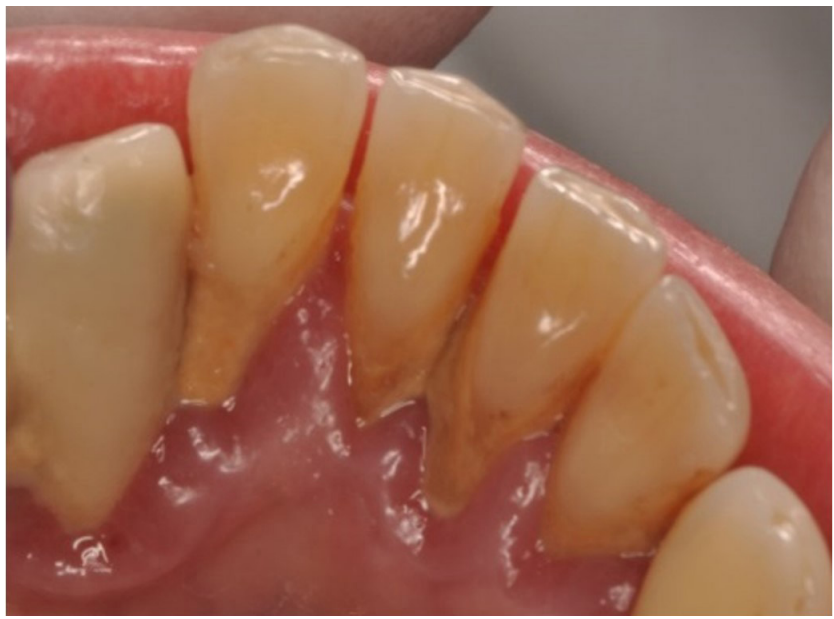

2. ábra

Magas rizikójú onkológiai beteg. A fogkő és a marginális parodontitis jelenléte növeli a MRONJ kialakulásának veszélyét

MRONJ = gyógyszer által indukált állcsontnecrosis

sal összefüggésbe nem hozható (non-surgery related) MRONJ-esetek 2\%-ában a kiváltó ok súlyos parodontitis volt. Számos esetbemutatás és retrospektív vizsgálat valószínúsíti egy kezdődő endodontalis eredetû́ gyulladás lehetséges szerepét $[22,30,31]$. Vescovi retrospektív vizsgálata szerint a 'non-surgery related' esetek 87,8\%ában nincs ismert kiváltó tényező [9], míg Marx és mtsai már 2005-ben leírták az endodontalis gyulladások szerepét a MRONJ kialakulásában. A betegek 10,9\%-ában periapicalis krónikus gyulladást diagnosztizáltak az osteonecrosist megelőzően [29].

A MRONJ kialakulásának szempontjából jelentőséggel bírnak bizonyos anatómiai képletek azoknál a pácienseknél, akik kivehetô fogpótlással rendelkeznek: torus mandibulae, exostosis palati és torus palatinus $[9,11]$ (3. ábra). Prediszponáló tényező a processus alveolarison található kifejezett csonttarajok jelenléte. Ilyen anatómiai viszonyok mellett kivehetô lemezes fogpótlás készítésekor fokozott gondossággal kell eljárni, hogy a későbbiekben a mechanikus irritációt ezekben az esetekben is elkerüljük [32]. A páciensek korábban készített,

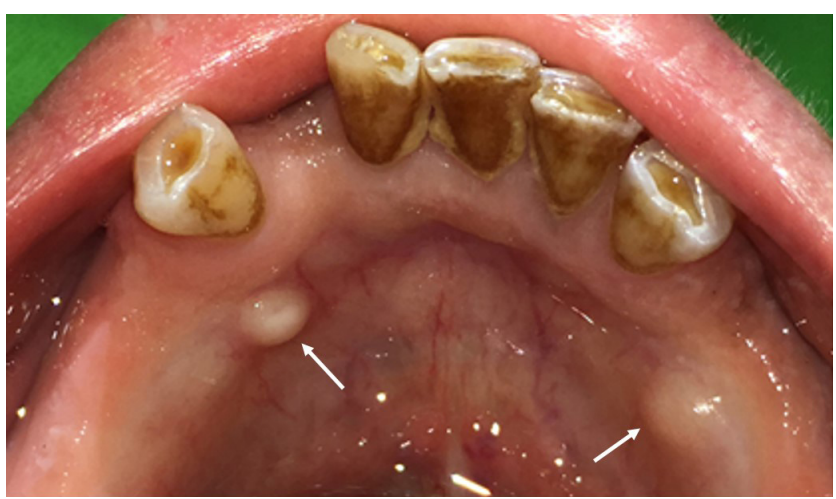

\begin{tabular}{l|l} 
3. ábra & Kivehető fogpótlással rendelkezóknél lokális rizikófaktor az alsó
\end{tabular} állcsonton található torus mandibulae rosszul illeszkedő kivehető fogpótlása is etiológiai faktorként szerepelhet a MRONJ kialakulásában. Egy átfogó olasz tanulmány szerint az invazív beavatkozással összefüggésbe nem hozható MRONJ-esetek 10,2\%-ánál a kiváltó tényező a fogpótlás okozta trauma volt [9]. A nyálkahártya tartós mechanikai irritációja következtében lokális gyulladás alakulhat ki, és a mikroorganizmusok a csont irányában hatolhatnak az amúgy is védekezésre képtelen csontállományba [26]. A 3. táblázat összefoglalja a lokális rizikófaktorokat.

3. táblázat | Lokális rizikófaktorok

\begin{tabular}{|c|c|}
\hline \multicolumn{2}{|l|}{ Lokális rizikótényezők } \\
\hline $\begin{array}{l}\text { Kivehető fogpótlással rendelkező } \\
\text { pácienseknél rizikót jelentő } \\
\text { anatómiai elváltozások }\end{array}$ & $\begin{array}{l}\text { Torus palatinus } \\
\text { Torus mandibulae } \\
\text { Exostosis palati } \\
\text { Kifejezett crista mylohyoidea } \\
\text { Kifejezett crista alveolaris }\end{array}$ \\
\hline $\begin{array}{l}\text { Rosszul illeszkedő kivehető } \\
\text { fogpótlás }\end{array}$ & \\
\hline $\begin{array}{l}\text { Periapicalis, parodontalis } \\
\text { gyulladás } \\
\text { Periimplantitis }\end{array}$ & $\begin{array}{l}\text { Parodontitis chronica } \\
\text { A periodontitis krónikus formái } \\
\text { Endoparodontalis laesio }\end{array}$ \\
\hline $\begin{array}{l}\text { Dentoalveolaris sebészi } \\
\text { beavatkozás }\end{array}$ & $\begin{array}{l}\text { Extrakció } \\
\text { A csontot érintő sebészi } \\
\text { beavatkozás (gyökércsúcs-reszek- } \\
\text { ció) } \\
\text { Parodontalis mútét } \\
\text { Implantáció }\end{array}$ \\
\hline
\end{tabular}

\section{Rizikócsoportok}

A kezelőorvos a lokális és a szisztémás rizikótényezők ismeretében rizikócsoportokba sorolhatja a pácienseket, ami a későbbiekben útmutatást adhat a kezelés kivitelezésében. A páciensek fogászati ellátásakor a prevenciós szemlélet a legfontosabb [22]. Ehhez tartozik rizikópáciensünk tájékoztatása is [33].

A MRONJ kialakulásának akkor a legkisebb a veszélye, ha a beteg a biszfoszfonát-, illetve denoszumabterápiát szanált száj- és fogazati statusszal kezdi meg. A gyógyszeres kezelés megkezdése előtt a társszakmák, például a reumatológusok és az onkológusok feladata, hogy fogorvoshoz irányítsák páciensüket. Ideális esetben a gyógyszer szedése előtt megtörténik a szájhigiéné rendezése, az esetlegesen jelen lévő gyulladások kezelése, a menthetetlen fogak extrakciója és a teljes szájüregi rehabilitáció. A nem helyreállítható vagy rossz és bizonytalan prognózisú fogak eltávolítandók, illetve amennyiben szükséges, elvégzendők az egyéb elektív dentoalveolaris beavatkozások. A sebgyógyulás idejét ki kell várni az antireszorptív terápia megkezdése előtt (3-4 hét) [11, 34]. Fogászati szűrôvizsgálatok után el kell végezni a szükséges konzerváló fogászati beavatkozásokat. A páciensek meglévő kivehető fogpótlását ellenőrizni kell, hogy igényel-e korrekciót, alábélelést, vagy szükséges-e új fogpótlás készítése. A rizikóbetegek tájékoztatása és oktatása elen- 
gedhetetlen, hogy ôk is tudatosan és mihamarabb orvoshoz forduljanak az általuk észrevett elváltozás esetén, és rendszeres kontrollra járjanak $[33,35]$. Ha az antireszorptív terápia nem késleltethető, a fogazat, a parodontium és a szájhigiéné rendezése az elkövetkezendő 3 hónapban történjen meg [8].

A már antireszorptív terápiában részesülő pácienseknél a fogorvosi kezelés előtt figyelembe veendő paraméterek a következők:

- az antireszorptív készítmény típusa (biszfoszfonát, denoszumab),

- az adminisztráció módja (iv., per os),

- a terápia indikációja (onkológiai, osteometabolicus),

- a terápia hossza években.

$\mathrm{Az}$ antireszorptív készítmény típusa a legfontosabb a rizikó mértékének kialakulásában. A biszfoszfonátok féléletideje meghaladja a szükséges több mint 10 évet is, akár egyszeri intravénás adagolást követően [36]. Közülük a zoledronsav a leginkább rizikót növelő tényező, mert antireszorptív és antiangiogenikus hatású egyben. Az egyéb NBP-ok és a denoszumab közepes kockázatú, a legkisebb rizikót pedig a nem aminobiszfoszfonátok jelentik.

Onkológiai betegségek esetén az intravénásan adagolt biszfoszfonátok jelentenek komoly rizikót a MRONJ kialakulása szempontjából $[17,37]$. Daganatos betegeknek jóval nagyobb dózisban kell adagolni a készítményt, mint osteoporosis esetén. Az intravénás alkalmazás teszi lehetővé a magasabb hatóanyag-koncentráció elérését a szervezetben $[33,37,38]$. Ez emeli a rizikót a per os alkalmazással szemben. Természetesen nagyon lényeges az adagolás gyakorisága is.

Az osteometabolicus indikációval kezelt pácienseknél kisebb rizikóval számolhatunk [14]. Di Fede és mtsai vizsgálata szerint a MRONJ elófordulása onkológiai indikációval kezelt beteg esetén 3-18\%, míg osteoporosis esetén $0,02-11 \%$ [17], így a daganatos betegek magasabb MRONJ-rizikóval rendelkeznek, mint az osteometabolicus betegek.

Az intravénásan alkalmazott zoledronsav-terápia esetén onkológiai betegeknél a MRONJ előfordulásának gyakorisága 2 év után már nem emelkedett, denoszumabterápia esetén ez 3 év után következett be [39, 40]. Osteoporosisos betegeknél a per os adagolt biszfoszfonátterápia alatt a MRONJ elöfordulása 4 év után érte el a maximumát [41, 42]. Minél hosszabb ideig kapja a páciens az antireszorptív terápiát, annál nagyobb a veszélye a szövődményes osteonecrosis kialakulásának.

Miután meghatároztuk az alapvető rizikófaktorokat, mérlegeljük a korábban említett további szisztémás és lokális tényezők szerepét.

A rizikóbetegeknél szigorú kontroll szükséges, hogy az esetleges gyulladást hamar felismerjük, és adekvát kezeléssel elimináljuk. Kontrollvizsgálatot 4-6 havonta ajánlott elvégezni [22]. A kontrollvizsgálatok gyakoriságát az előzőekben felsorolt rizikófaktorok határozzák meg. Sűrübb kontrollt igényelnek az onkológiai bete- gek, akik intravénásan kapják az antireszorptív kezelést, vagy akiknél már hosszú ideje fennáll a terápia, illetve számos más társbetegségben szenvednek, és egyéb szupportív kezelést is kapnak. A már antireszorptív kezelésben részesülő páciensek speciális protokoll szerinti ellátásban kell, hogy részesüljenek.

Onkológiai pácienseknél az esetlegesen felfedezett gyulladás kezelése minél hamarabb meg kell, hogy történjen. Konzerváló fogászati beavatkozás mindenképpen javallt, ha az adott fog megmenthető, és így az esetleges extrakció elkerülhető $[37,43]$. Az elektív sebészi beavatkozás kontraindikált [34]. Nem helyreállítható fog esetében a fogat dekoronáljuk [44], és gyökérkezelést követően üvegionomer cementtel vagy kompozittöméssel zárjuk. Implantátumok beültetése kontraindikált [8, 22]. Ha a gyulladás kezelése sikertelen, sebészi beavatkozással csökkenthető a MRONJ kockázata. Egyes szerzőknél felmerül az úgynevezett 'drug holiday', vagyis a biszfoszfonátterápiának az invazív beavatkozás előtt 2 hónappal való felfüggesztése. A 2014. évi MOTESZkonszenzus alapján a 'drug holiday' nagyobb veszéllyel jár az onkológiai páciensek alapbetegségének prognózisát tekintve, így ez nem alkalmazandó módszer [8]. Amennyiben a fog eltávolítására vagy egyéb szájsebészeti beavatkozásra lenne szükség, minden esetben minimálinvazív megoldásokra törekszünk $[22,34]$. A beavatkozást antibiotikus védelemben végezzük, a következók szerint: 1000-2000 mg amoxicillin + klavulánsav/nap (Augmentin Duo $2 \times 1$, Augmentin $500 \mathrm{mg} / 125 \mathrm{mg} 3$ $\times 1)$, penicillinallergia esetén $1200 \mathrm{mg}$ klindamicin/nap (Dalacin $\mathrm{C} 4 \times 1$ ). Az antibiotikumot a páciens a beavatkozás előtt 2 nappal kezdi el szedni, majd még 1 hétig folytatja [8]. Ajánlott az orális antiszeptikum, például klór-hexidin használata mútét előtt és után [45]. A csonthártyát érintő mütéti beavatkozások lehetőség szerint kerülendők. A MRONJ kezelését arc-állcsont-száj sebész végezze [8]. A periapicalis, parodontalis gyulladást okozó baktériumok a periodontalis résen át könynyen elérik a csontszövetet $[38,44,46]$. Ez magas rizikófaktort jelent a MRONJ kialakulása szempontjából. A MRONJ előzményeként és feltételezett kiváltó tényezőjeként a legtöbbször az extrakció szerepel [26]. Felmerül azonban, hogy a fennálló periapicalis gyulladások talaján is kialakulhat MRONJ [28]. A konzerváló fogászati ellátásokat - mint például tömés, gyökérkezelés fokozott elővigyázatossággal kell a fogorvosnak kivitelezni [22, 31]. Endodontiai beavatkozás során a munkahossz-meghatározásig antibiotikumprofilaxisban kell részesíteni a rizikópácienst egy órával a beavatkozás előtt (amoxicillin + klavulánsav $2 \times 1,0 \mathrm{~g}$, penicillinallergia esetén klindamicin $2 \times 300 \mathrm{mg}$ ). A gyökérkezelés ezen fázisában jutunk túl a foramen physiologicumon a periapicalis térbe [31]. Tömések készítésekor az üregalakítást követően, illetve gyökérkezeléskor abszolút izolációban végezzük a kezelést, amelyhez hozzátartozik, hogy az izolációhoz használt gumilepedőt egy kapoccsal rögzítjük a fogon. A kapocs felhelyezésekor figyelni kell, 


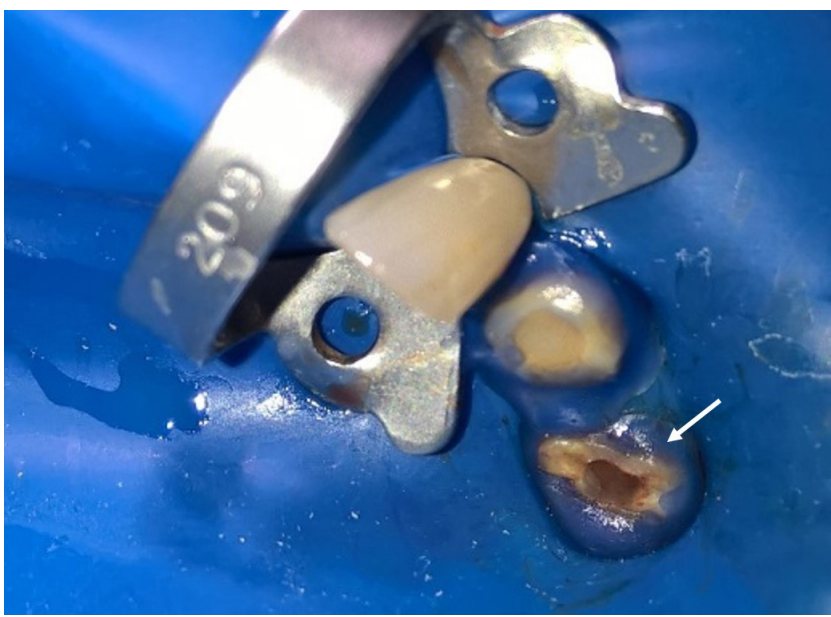

4. ábra

Preventív szemléletű, atraumatikus izolálás 24 fog (FDI jelölés szerint) endodontiai beavatkozása során

hogy a gingivát ne traumatizáljuk, ne helyezzük rá a kapcsot (4. ábra). A traumatikus kapocsfelhelyezés a biológiai szélesség sérülését okozza, amely triggere lehet a MRONJ kialakulásának [47]. A biszfoszfonátterápiában részesülők protetikai ellátásakor a következőket kell figyelembe venni: rögzített fogpótláshoz a fogakat supragingivalis vállal készítse elő a fogorvos, hogy a korona széle jól kontrollálható és tisztítható legyen (5. ábra). Kivehető fogpótlások esetében rendszeres ellenőrzéssel, szükség esetén korrekcióval kerülhető el a decubitus [22]. Manifeszt MRONJ-os páciensnél a mucosa terhelését csökkenthetjük kiegyensúlyozott okklúziós viszonyok kialakításával és az okklúzió és az artikuláció 3-4 havonkénti kontrolljával [48], valamint lehetőség szerint dentalis megtámasztású fogpótlással [49].

A MRONJ kialakulásának veszélye osteometabolicus indikáció esetén kisebb, mint onkológiai esetén [14], továbbá kevésbé súlyos a MRONJ manifesztációja, és a terápiára is jobban reagál, mint az onkológiai indikációval kezelt betegeknél [50]. Az elektív dentoalveolaris sebészeti beavatkozás ebben a csoportban nem ellenjavallt [22].

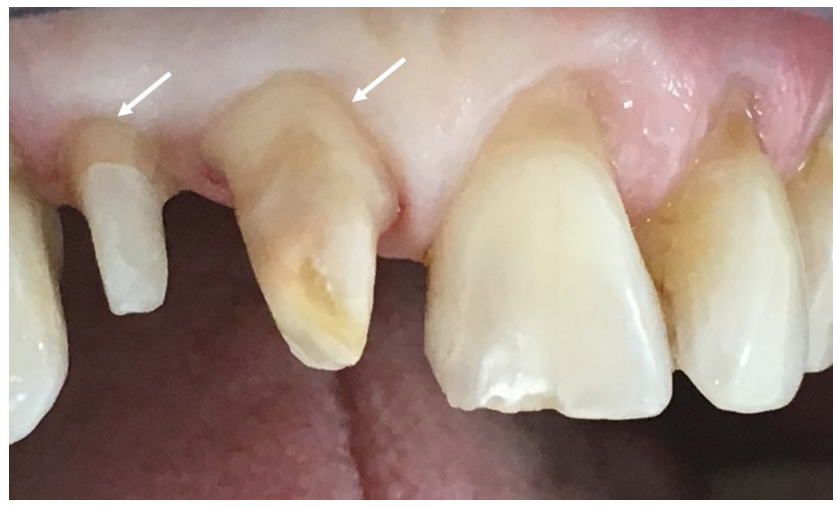

5. ábra

| Paragingivalis vállal előkészített csonkok fix pótláshoz

\section{Következtetés}

A rizikócsoportba tartozás határozza meg a lehetséges kezelések indikációját, kontraindikációját. A különböző rizikófaktorok halmozódása határozza meg a necrosis kialakulásának valószínúségét. Magas MRONJ-rizikóval számolunk, ha a páciens onkológiai indikációval intravénás biszfoszfonátterápiában részesül több mint 2 éve. Tovább növeli a necrosis kialakulásának veszélyét, ha a beteg szupportív terápiában részesül, társbetegségekben szenved, és időskorú (1. és 2. táblázat).

Mindegyik rizikócsoportban kiemelt hangsúlyt kell fektetni a prevencióra, tájékoztatásra, mind a fogorvosnak, mind a társszakmák kezelöorvosainak [22, 33]. Az optimális cél érdekében nélkülözhetetlen az együttmúködés és a folyamatos kommunikáció az orvoskollégák között. Elsődleges a rizikófaktorok felismerése, majd a páciens rizikócsoportba sorolása, ennek megfelelő további ellátása és útjának végigkísérése. A terápiában esetlegesen felmerülő változásokat, a kezelési tervben történő módosításokat a kezelőorvosok - onkológus, reumatológus, arc-, állcsont- és szájsebész, illetve fogorvos - együttes döntés alapján, összhangban kell, hogy megtegyék.

A MRONJ-prevenció a biszfoszfonát- és adenoszumabterápia megkezdése előtt és közben is elengedhetetlen. Mindez magában foglalja a sztomatoonkológiai szúrôvizsgálatot, a szájhigiéné optimalizálását, a profeszszionális szájhigiénés kezeléseket, orális antiszeptikumok használatát [31], a carieses fogak, periapicalis és parodontalis gyulladások kezelését [34]. A gyulladás leküzdésére elsődlegesen a legkevésbé invazív módszert kell választani. Magas rizikójú betegek esetén pulpalis és periapicalis betegségekben akkor is az endodontiai beavatkozást kell választani, ha a fog funkcionálisan és esztétikailag nem állítható helyre [11]. Ha mégis extrakcióra vagy más dentoalveolaris beavatkozásra kerül sor, azt antibiotikus terápiás védelemben szükséges végezni [8].

Anyagi támogatás: A közlemény megírása és a kapcsolódó kutatómunka anyagi támogatásban nem részesült.

Szerzői munkamegosztás: A szerzők mindannyian részt vettek az irodalmi kutatómunkában és a kézirat elkészítésében. A cikk végleges változatát valamennyi szerző elolvasta és jóváhagyta.

Érdekeltségek: A szerzőknek nincsenek érdekeltségeik.

\section{Irodalom}

[1] Reszka AA, Rodan GA. Nitrogen-containing bisphosphonate mechanism of action. Mini Rev Med Chem. 2004; 4: 711-719.

[2] Hall A. Rho GTPases and the actin cytoskeleton. Science 1998; 279: 509-514.

[3] Luckman SP, Hughes DE, Coxon FP, et al. Nitrogen-containing bisphosphonates inhibit the mevalonate pathway and prevent 
post-translational prenylation of GTP-binding proteins, including Ras. J Bone Miner Res. 1998; 13: 581-589.

[4] Russell RG. Bisphosphonates: from bench to bedside. Ann N Y Acad Sci. 2006; 1068: 367-401.

[5] Hanley DA, Adachi JD, Bell A, et al. Denosumab: mechanism of action and clinical outcomes. Int J Clin Pract. 2012; 66: 11391146.

[6] Soós B, Vajta L, Szalma J. Sunitinib and zoledronic acid induced osteonecrosis of the jaw. [Sunitinib és zoledronsav által indukált állcsont-osteonecrosis.] Orv Hetil. 2015; 156: 1865-1870. [Hungarian]

[7] Janovszky Á, Vereb T, Szabó A. et al. Current approaches for early detection and treatment of medication-related osteonecrosis of jaw. [Aktuális trendek a gyógyszer indukálta állcsontnecrosis korai felismerése és kezelési stratégiája terén.] Orv Hetil 2014; 155: 1960-1966. [Hungarian]

[8] Magyar Arc-, Állcsont- és Szájsebészeti Társaság, Magyar Osteoporosis és Osteoarthrológiai Társaság, Magyar Onkológusok Társasága, Magyar Reumatológusok Egyesülete, Magyar Ortopéd Társaság. Bisphosphonate-induced jaw osteonecrosis - prevention and treatment. [A biszfoszfonátok által indukált állcsontosteonecrosisok megelőzése és kezelése.] Orv Hetil. 2010; 151: 148-149. [Hungarian]

[9] Vescovi P, Campisi G, Fusco V, et al. Surgery-triggered and non surgery-triggered bisphosphonate-related osteonecrosis of the jaws (BRONJ): a retrospective analysis of 567 cases in an Italian multicenter study. Oral Oncol. 2011; 47: 191-194.

[10] Bamias A, Kastritis E, Bamia C, et al. Osteonecrosis of the jaw in cancer after treatment with bisphosphonates: incidence and risk factors. J Clin Oncol. 2005; 23: 8580-8587.

[11] Ruggiero SL, Dodson TB, Fantasia J, et al. American Association of Oral and Maxillofacial Surgeons position paper on medication-related osteonecrosis of the jaw - 2014 update. J Oral Maxillofac Surg. 2014; 72: 1938-1956.

[12] Qi WX, Tang LN, He AN, et al. Risk of osteonecrosis of the jaw in cancer patients receiving denosumab: a meta-analysis of seven randomized controlled trials. Int J Clin Oncol. 2014; 19: 403410.

[13] Smith MR, Saad F, Coleman R, et al. Denosumab and bonemetastasis-free survival in men with castration-resistant prostate cancer: results of a phase 3 , randomised, placebo-controlled trial. Lancet 2012; 379: 39-46.

[14] Gaudin E, Seidel L, Bacevic M, et al. Occurrence and risk indicators of medication-related osteonecrosis of the jaw after dental extraction: a systematic review and meta-analysis. J Clin Periodontol. 2015; 42: 922-932.

[15] Badros A, Weikel D, Salama A, et al. Osteonecrosis of the jaw in multiple myeloma patients: clinical features and risk factors. J Clin Oncol. 2006; 24: 945-952.

[16] Palaska PK, Cartsos V, Zavras AI. Bisphosphonates and time to osteonecrosis development. Oncologist 2009; 14: 1154-1166.

[17] Di Fede O, Fusco V, Matranga D, et al. Osteonecrosis of the jaws in patients assuming oral bisphosphonates for osteoporosis: a retrospective multi-hospital-based study of 87 Italian cases. Eur J Intern Med. 2013; 24: 784-790.

[18] Jadu F, Lee L, Pharoah M, et al. A retrospective study assessing the incidence, risk factors and comorbidities of pamidronate-related necrosis of the jaws in multiple myeloma patients. Ann Oncol. 2007; 18: 2015-2019.

[19] Chiu CT, Chiang WF, Chuang CY, et al. Resolution of oral bisphosphonate and steroid-related osteonecrosis of the jaw - a serial case analysis. J Oral Maxillofac Surg. 2010; 68: 1055-1063.

[20] Van Cann T, Loyson T, Verbiest A. Incidence of medication-related osteonecrosis of the jaw in patients treated with both bone resorption inhibitors and vascular endothelial growth factor receptor tyrosine kinase inhibitors. Support Care Cancer 2018; 26: 869-878.
[21] Vaszilko M, Kovacs E, Restar L, et al. Potential significance of antiestrogen therapy in the development of bisphosphonate related osteonecrosis of the jaw. J Craniomaxillofac Surg. 2014; 42: 1932-1936.

[22] Campisi G, Lo Russo L, Agrillo A, et al. BRONJ expert panel recommendation of the Italian Societies for Maxillofacial Surgery (SICMF) and Oral Pathology and Medicine (SIPMO) on Bisphosphonate-Related Osteonecrosis of the Jaws: risk assessment, preventive strategies and dental management. J Maxillofac Surg. 2011; 22: 103-124.

[23] Wessel JH, Dodson TB, Zavras AI. Zoledronate, smoking, and obesity are strong risk factors for osteonecrosis of the jaw: a casecontrol study. J Oral Maxillofac Surg. 2008; 66: 625-631.

[24] Yang G, Hamadeh IS, Katz J, et al. SIRTI/HERC4 locus associated with bisphosphonate-induced osteonecrosis of the jaw: an exome-wide association analysis. J Bone Miner Res. 2018; 33 : 91-98.

[25] Vaszilko M, Barabás J, Szabó Gy, et al. Osteonecrosis of the jaws by using bisphosponates. [Biszfoszfonátok alkalmazása következtében kialakuló osteonecrosis az állcsontokban.] Fogorv Szle. 2007; 100: 115-119. [Hungarian]

[26] Vahtsevanos K, Kyrgidis A, Verrou E, et al. Longitudinal cohort study of risk factors in cancer patients of bisphosphonate-related osteonecrosis of the jaw. J Clin Oncol. 2009; 27: 5356-5362.

[27] McGowan K, McGowan T, Ivanovski S. Risk factors for medication-related osteonecrosis of the jaws: A systematic review. Oral Dis. $2018 ; 24: 527-536$.

[28] Association of Hungarian Medical Societies. The prevention and treatment of bisphosphonate-induced osteonecrosis of the jaw II. [Magyar Orvostársaságok és Egyesületek Szövetsége. A biszfoszfonátok által indukált állcsont oszteonekrózisok megelőzése és kezelése II.] Fogorv Szle. 2014; 107: 106-107. [Hungarian]

[29] Marx RE, Sawatari Y, Fortin M, et al. Bisphosphonate-induced exposed bone (osteonecrosis/osteopetrosis) of the jaws: risk factors, recognition, prevention, and treatment. J Oral Maxillofac Surg. 2005; 63: 1567-1575.

[30] Katz H. Endodontic implications of bisphosphonate-associated osteonecrosis of the jaws: a report of three cases. J Endod. 2005; 31: 831-834.

[31] Moinzadeh AT, Shemesh H, Neirynck NA, et al. Bisphosphonates and their clinical implications in endodontic therapy. Int Endod J. 2013; 46: 391-398.

[32] Filleul O, Crompot E, Saussez S. Bisphosphonate-induced osteonecrosis of the jaw: a review of 2,400 patient cases. J Cancer Res Clin Oncol. 2010; 136: 1117-1124.

[33] Migliorati CA, Mattos K, Palazzolo MJ. How patients' lack of knowledge about oral bisphosphonates can interfere with medical and dental care. J Am Dent Assoc. 2010; 141: 562-566.

[34] Campisi G, Di Fede O, Musciotto A, et al. Bisphosphonate-related osteonecrosis of the jaw (BRONJ): run dental management designs and issues in diagnosis. Ann Oncol. 2007; 18(Suppl 6): vil68- vil72.

[35] Otto S, Pautke C, Van den Wyngaert T, et al. Medication-related osteonecrosis of the jaw: prevention, diagnosis and management in patients with cancer and bone metastases. Cancer Treat Rev. 2018; 69: 177-187.

[36] Khan SA, Kanis JA, Vasikaran S, et al. Elimination and biochemical responses to intravenous alendronate in postmenopausal osteoporosis. J Bone Miner Res. 1997; 12: 1700-1707.

[37] Kyrgidis A, Vahtsevanos K, Koloutsos G, et al. Bisphosphonaterelated osteonecrosis of the jaws: a case-control study of risk factors in breast cancer patients. J Clin Oncol. 2008; 26: 46344638.

[38] Woo SB, Hellstein JW, Kalmar JR. Narrative [corrected] review: bisphosphonates and osteonecrosis of the jaws. Ann Intern Med. 2006; 144: 753-761. 
[39] Henry DH, Costa L, Goldwasser F, et al. Randomized, doubleblind study of denosumab versus zoledronic acid in the treatment of bone metastases in patients with advanced cancer (excluding breast and prostate cancer) or multiple myeloma. J Clin Oncol. 2011; 29: 1125-1132.

[40] Saad F, Brown JE, Van Poznak C, et al. Incidence, risk factors, and outcomes of osteonecrosis of the jaw: integrated analysis from three blinded active-controlled phase III trials in cancer patients with bone metastases. Ann Oncol. 2012; 23: 13411347.

[41] Lo JC, O'Ryan FS, Gordon NP, et al. Prevalence of osteonecrosis of the jaw in patients with oral bisphosphonate exposure. J Oral Maxillofac Surg. 2010; 68: 243-253.

[42] United States Food and Drug Administration. Background Document for Meeting of Advisory Committee for Reproductive Health Drugs and Drug Safety and Risk Management Advisory Committee. Silver Spring, MD, September 9, 2011. Available from: Committees/CommitteesMeetingMaterials/drugs/DrugSafetyandRiskManagementAdvisoryCommittee/ucm270958. pdf [accessed: February 10, 2014].

[43] Dereci Ö, Orhan EO, Irmak Ö, et al. The effect of the duration of intravenous zolendronate medication on the success of nonsurgical endodontic therapy: a retrospective study. BMC Oral Health 2016; 16: 9.

[44] Ruggiero S, Gralow J, Marx RE, et al. Practical guidelines for the prevention, diagnosis, and treatment of osteonecrosis of the jaw in patients with cancer. J Oncol Pract. 2006; 2: 7-14.

[45] Lodi G, Sardella A, Salis A, et al. Tooth extraction in patients taking intravenous bisphosphonates: a preventive protocol and case series. J Oral Maxillofac Surg. 2010; 68: 107-110.
[46] Yoneda T, Hagino H, Sugimoto T, et al. Bisphosphonate-related osteonecrosis of the jaw: position paper from the Allied Task Force Committee of Japanese Society for Bone and Mineral Research, Japan Osteoporosis Society, Japanese Society of Periodontology, Japanese Society for Oral and Maxillofacial Radiology, and Japanese Society of Oral and Maxillofacial Surgeons. J Bone Miner Metab. 2010, 28: 365-383.

[47] Gallego L, Junquera L, Pelaz A, et al. Rubber dam clamp trauma during endodontic treatment: a risk factor of bisphosphonaterelated osteonecrosis of the jaw? J Oral Maxillofac Surg. 2011; 69: e93-e95.

[48] American Dental Association Council on Scientific Affairs. Dental management of patients receiving oral bisphosphonate therapy: expert panel recommendations. J Am Dent Assoc. 2006; 137: 1144-1150.

[49] Göllner M, Holst S, Fenner M, et al. Prosthodontic treatment of a patient with bisphosphonate-induced osteonecrosis of the jaw using a removable dental prosthesis with a heat-polymerized resilient liner: a clinical report. J Prosthet Dent. 2010; 103: 196201.

[50] Marx RE, Cillo JE Jr, Ulloa JJ. Oral bisphosphonate-induced osteonecrosis: risk factors, prediction of risk using serum CTX testing, prevention, and treatment. J Oral Maxillofac Surg. 2007; 65: $2397-2410$.

\section{„Etiam capillus unus habet umbram suam." (Egyetlen hajszálnak is megvan a maga árnyéka.)}

A cikk a Creative Commons Attribution 4.0 International License (https://creativecommons.org/licenses/by/4.0/) feltételei szerint publikált Open Access közlemény, melynek szellemében a cikk bármilyen médiumban szabadon felhasználható, megosztható és újraközölhetö, feltéve, hogy az eredeti szerző és a közlés helye, illetve a CC License linkje és az esetlegesen végrehajtott módositások feltüntetésre kerülnek. (SID_1) 